\title{
Semen quality of three breeds of exotic boar extended using methaloninated Moringa leaf extract as antibiotics in beltsville thawing solution
}

Omodewu, I. A ${ }^{1}$., Olorungbohunmi, T ${ }^{1}$., Boladuro, B. A ${ }^{1}$., Abiona, J. O ${ }^{2}$., and C. P. Njoku³ . ${ }^{1}$ Institute of Agricultural Research and Training, Moor Plantation, Ibadan

${ }^{2}$ Department of Animal Physiology, ${ }^{3}$ Department of Animal Production and Health, Federal University of Agriculture, Abeokuta

Abstract

Corresponding author: Ifeayo24@yahoo.com; 08167330502

Moringa oleifera leaf extract (MLE) contains antibacterial properties; this study evaluated the effect of including MLE, breed and storage time on semen quality of boars extended with Beltsville thawing solution (BTS). Semen samples were collected weekly from twelve boars (Four Duroc, four Large White and four Landrace). Samples were extended with 0, 0.25, 0.50, 0.75 and $1.00 \mathrm{~g}$ MLE inclusions. Parameters; volume and concentration were taken immediately after collection while $\mathrm{pH}$, mass activity (\%MA), progressive motility (\%PM), liveability (\%LA) and abnormality $(\% A B N)$ were taken at $0,24,48$ and 72 hours. Data obtained were subjected to analysis of variance. All parameters considered except $\% A B N$ were significant $(p<0.05)$. MA ranged between $3.31(1.00 \mathrm{gMLE})$ and $4.00(0 \mathrm{gMLE})$. Highest $P M$ was $60.93 \%$ in $0.25 \mathrm{gMLE}$, pH differed with 6.98 (0gMLE) and 6.90 (1.00gMLE), OgMLE (89.64\%) had higher LA compared to $0.25 \mathrm{gMLE}$ (86.40\%), ABN ranged between 3.94 to $4.60 \%$. As storage time increased viability of all semen parameters reduced, between 48 and 72 hours parameters reduced below normal limits. Breed effect differed $(p<0.05)$ for MA, Volume and Conc., Duroc (3.78) had higher MA compared to Large White (3.64) and Landrace (3.60). Semen volume $(p<0.05)$ for Landrace $(255.20 \mathrm{~g})$ was highest while Duroc $(170.80 \mathrm{~g})$ was lowest. Large white concentration (201.8million spermatozoa/ml) was higher $(p<0.05)$ than Landrace (187.4 million spermatozoa/ml) and Duroc (123.8million spermatozoa $/ \mathrm{ml}$ ). \%LA ranged between $88.06 \%$ and $88.72 \%$ for Duroc and landrace respectively while \%ABN was between 3.97-4.41\% for Large White and Landrace. This study concluded that 0.75-1.00gMLE could replace synthetic antibiotic in BTS for 24 hours.

Keywords: Boar, Semen extender, Moringa, Extract, Breed, antibiotics

\section{La qualité du sperme de trois races de verrats exotiques prélevés à l'aide d'extrait de feuille de Moringa méthaloniné comme antibiotique dans la solution de décongélation de 'Beltsville'}

\section{Résumé}

L'extrait de feuille de Moringa oleifera (le 'MLE') contient des propriétés antibactériennes ; Cette étude a évalué l'effet de l'inclusion de 'MLE', de la race et du temps de stockage sur la qualité du sperme de verrats exotiques additionnés de solution de décongélation de Beltsville (le 'BTS'). Des échantillons de sperme ont été prises chaque semaine de douze verrats (quatre Duroc, quatre Large White et quatre Landrace). Les échantillons ont été étendus avec des inclusions de 0, 0,25, 0,50, 0,75 et 1,00 g de 'MLE'. Paramètres ; le volume et la concentration ont été prélevés immédiatement après le prélèvement tandis que le $\mathrm{pH}$, l'activité massique (\% 'MA'), la motilité progressive (\% 'PM'), l'habitabilité (\% LA) et l'anomalie (\% ABN) ont été pris à 0, 24, 48 et 72 heures. Les données obtenues ont été soumises à une analyse de variance. Tous les paramètres considérés à l'exception du\% ABN étaient significatifs ( $p<0,05)$. Le MA variait entre 3,31 (1,00 g MLE) et 4,00 (0 gMLE). La 
'PM la plus élevée était de 60,93\% dans 0,25 gMLE, le pH différait de 6,98 (0 gMLE) et 6,90 (1,00 gMLE), 0 gMLE (89,64\%) avait un LA plus élevé par rapport à 0,25 gMLE (86,40\%), $l^{\prime \prime} A B N^{\prime}$ variait entre 3,94 et 4,60\%. À mesure que la durée de stockage augmentait la viabilité de tous les paramètres du sperme, entre 48 et 72 heures, les paramètres étaient réduits en dessous des limites normales. L'effet de la race était différent $(p<0,05)$ pour la MA, le volume et la concentration. Duroc $(3,78)$ avait une MA plus élevée que le Large White $(3,64)$ et le Landrace $(3,60)$. Le volume de sperme $(p<0,05)$ pour Landrace $(255,20 \mathrm{~g})$ était le plus élevé, tandis que Duroc $(170,80 \mathrm{~g})$ était le plus faible. La grande concentration de blanc (201,8 millions de spermatozoïdes / $\mathrm{ml})$ était plus élevée $(p<0,05)$ que Landrace $(187,4$ millions de spermatozoïdes / $\mathrm{ml}$ ) et Duroc $(123,8$ millions de spermatozoïdes / $\mathrm{ml})$. \% LA variait entre $88,06 \%$ et $88,72 \%$ pour Duroc et landrace respectivement tandis que\% ABN était entre 3,97-4,41\% pour Large White et Landrace. Cette étude a conclu que 0,75-1,00 gMLE pouvait remplacer l'antibiotique synthétique dans le BTS pendant 24 heures.

Mots clés: Verrats, Extenseur de sperme, Moringa, Extrait, Race, antibiotiques

\section{Introduction}

Semen diluent (extenders) increases the volume of semen, provide nutrients for metabolism, protect against cold shock, provide electrolytes for osmotic pressure and buffer against extremes in $\mathrm{pH}$ (Levis, 2000). Bacteria are normal component of the boar ejaculate (Sone et al., 1990) and their effect on samples are usually concentration and time dependent. They negatively affect quality and shell life of semen and may infect the reproductive tract of the female. These are pointers to the importance of antibiotics in extension and storage of semen for successful insemination. For this reason, semen extenders contain at least one antibiotic to combat bacteriospermia. However, antibiotic resistance and use restrictions are challenges experienced with synthetic antibiotics. Also, the development of multidrug resistant bacteria which has become an issue of concern and the control placed on the usage of some synthetic antibiotics (Casewell et al., 2003), mandated the need to look into naturally available alternative sources of antibiotics that can be utilized in boar semen processing. Moringa contains pterygospermin which has powerful broad spectrum antibacterial and fungicidal effects (Rao et al., 1946). The leaves of
Moringa oleifera have also been reported to be a valuable source of macro- and micronutrients, rich source of $\beta$-carotene, protein, vitamin $C$, calcium, potassium and act as a good source of natural antioxidants (Siddhuraju and Becker, 2003). Components of Moringa preparation have been reported to have antibacterial activity which include 4-(4'-O-acetyl- $\alpha-\mathrm{L}$ rhamnopyranosyloxy) benzyl is iothiocyanate, niazimicin, pterygospermin and $4-(\alpha-\mathrm{L}-$ rhamnopyranosyloxy) benzyl glucosinolate (Fahey et al., 2005). This study evaluated the effect of replacing the antibiotics in Beltsville thawing solution (a common boar extender) with Moringa oleifera leaf extract (MLE) on Semen quality characteristics.

\section{Materials and methods Experimental site}

The experiment was carried out at the Artificial Insemination Centre of the Institute of Agricultural Research and Training, Ibadan (I.A.R \& T) in Ikenne, Ogun state. The experimental location is situated within South Western part of Nigeria. Ikenne (Latitude $6^{0} 55^{\prime} \mathrm{N}$, longitude $30^{\circ} 35^{\prime} \mathrm{E}$ ) is located within the rain forest belt of Nigeria with annual rainfall between 1200 and 1900 mm (Google Earth, 2015). 


\section{Omodewu, Olorungbohunmi, Boladuro, Abiona and Njoku}

\section{Experimental animals and management}

A total of 12 exotic boars of different breeds and of similar age (2year) and weight (100$150 \mathrm{~kg}$ ) namely 4 Large White, 4 Landrace, 4 Duroc were used for the experiment. The boars were housed in open sided pen with feeding and drinking facilities. All boars were fed balanced compounded ration that met the maintenance requirement for breeding boars set by the NRC (2005).

\section{Experimental procedure}

The animals were randomly allotted into treatments. The Beltsville Thawing Solution (BTS) used to reconstitute the semen was constituted from: Glucose $39.1 \mathrm{~g}$, Sodium bicarbonate $1.32 \mathrm{~g}$, Trisodium citrate $1.32 \mathrm{~g}$, EDTA $1.32 \mathrm{~g}$, Potassium chloride $0.79 \mathrm{~g}$, Streptomycin $1.1 \mathrm{~g}$, Penicillin (IU/ml) $1.1 \mathrm{~g}$ and $1000 \mathrm{ml}$ Distilled water. They were constituted in a conical flask with pre-warmed distilled water at a temperature of $35^{\circ} \mathrm{C}$. Semen collection was done using the gloved-hand technique as described King and Macpherson (1973). The boars were taken individually to the collection pen where the 'dummy sow' is housed. A sterile styrofoam cup (semen collection cup) that had been pre-warmed to about $36{ }^{\circ} \mathrm{C}$ (to prevent cold shock) whose top was covered with a filter paper placed in the thermo-flask for semen collection. The filter paper was placed on the cup to separate the gelatinous substance (tapioca) from the sperm-rich fraction during the process of semen collection. After the boar had mounted the dummy sow, the prepuce was cleaned with tissue paper. A vinyl glove was worn on both hands, the collection cup placed in the thermo-flask was held with the other hand. The gloved-hand was used to hold the penis and the pre-seminal fluid was allowed to flow out before the sperm-rich fraction was carefully collected into the cup. The semen was then extended with the constituted Beltsville thawing solution at a ratio 1:10.
Moringa leaf extract (MLE) was added to the extender at $0,0.25,0.50,0.75$ and $1.00 \mathrm{~g}$ per $1000 \mathrm{ml}$ extender, respectively

Methanolic extraction of Moringa oleifera leaf

Fresh Moringa Oleifera leaves were obtained from Bora Farm of the Institute of Agricultural Research and Training (I. A. R $\&$ T.) Ibadan. The leaves were air dried for two weeks and $2000 \mathrm{~g}$ of the powdered leaves was extracted with $500 \mathrm{ml}$ of $70 \%$ methanol for 72 hours. The mixture was filtered and extracted on a water bath for evaporation and solidification of the extract (Afolabi et al., 2013).

\section{Data collection}

The semen samples were extended and evaluated for semen quality parameters such as mass activity, progressive motility, percentage liveability and abnormality using a light microscope at $0 \mathrm{hr}, 24 \mathrm{hrs}, 48$ hrs and $72 \mathrm{hrs}$ respectively. The $\mathrm{pH}$ of the samples was determined using an electronic $\mathrm{pH}$ meter at the different hours. The samples were stored at $17^{\circ} \mathrm{C}$ while the assessment of the semen quality parameters was done as described in Ewuola and Egbunike (2010). The experimental design was a $3 \times 4 \times 4$ arrangement in a completely randomised design and the factors were breed, MLE inclusion and time respectively.

\section{Statistical analysis}

The collected data were subjected to analysis of variance (ANOVA) using SAS (2003). Significant mean values were separated using Duncan's Multiple Range Test (DMRT).

\section{Results and discussion}

The effect of breed on semen parameters of exotic boar extended with Beltsville thawing solution with varying levels of Moringa leaf extract as replacement for synthetic antibiotics

As shown in Table 1 (breed effect), mass activity significantly differed $(\mathrm{p}<0.05)$, Duroc had highest mass activity (3.78) 
while Large White (3.64) and Landrace (3.60) had similar values, this range fall within the recommendation of Shipley (1999) and Johnson et al. (2000). Sperm cell concentration also differed $(\mathrm{p}<0.05)$, Large white had the highest $\left(201.8 \times 10^{\wedge} 6\right.$ sperms $/ \mathrm{ml})$ and Duroc $\left(123.80 \times 10^{\wedge} 6\right.$ sperms $/ \mathrm{ml}$ ) the lowest, all the breeds had their concentration within normal limit recommended by Hafez (1993), Kommisrud et al. (2002) and Turba et al. (2007). The concentration obtained from Duroc and Large white were similar to those reported by Kommisrud et al. (2002). It was reported that differences arise from genetic differences, environmental factors, nutrition and method used in assessing concentration. Semen volume was also significant $(\mathrm{p}<0.05)$, Landrace $(255.20 \mathrm{ml})$ was higher than those of Large white $(222.00 \mathrm{ml})$ and Duroc $(170.80 \mathrm{ml})$ the result coincides with reports by Kommisrud et al. (2002) and Johnson et al. (2000). Breed had no effect on progressive motility, $\mathrm{pH}$, liveability, abnormality and semen temperature.

Table 1: The effect of breed on semen parameters of exotic boar semen extended Beltsville thawing solution (BTS)

\begin{tabular}{lllllllll}
\hline Breed & MA & PM & pH & LA & ABN & $\begin{array}{l}\text { Conc } \\
(\text { million } \\
\text { sperm/ml) }\end{array}$ & Vol (ml) & $\begin{array}{l}\text { Temp } \\
{ }^{0} \mathrm{C}\end{array}$ \\
\hline Duroc & $3.78^{\mathrm{a}}$ & 59.26 & 6.93 & 88.06 & 4.35 & $123.8^{\mathrm{c}}$ & $170.80^{\mathrm{c}}$ & 37.66 \\
Landrace & $3.60^{\mathrm{b}}$ & 57.41 & 6.93 & 88.72 & 4.41 & $187.4^{\mathrm{b}}$ & $255.20^{\mathrm{a}}$ & 37.38 \\
LargeWhite & $3.64^{\mathrm{b}}$ & 58.42 & 6.94 & 88.26 & 3.97 & $201.8^{\mathrm{a}}$ & $222.00^{\mathrm{b}}$ & 37.64 \\
\pm SEM & 0.03 & 0.629 & 0.011 & 0.427 & 0.216 & 9.012 & 8.451 & 0.052 \\
\hline
\end{tabular}

Means with different superscript $\mathrm{a}, \mathrm{b}, \mathrm{c}$ and $\mathrm{d}( \pm$ SEM) in the same column are significantly different $(\mathrm{p}<0.05) * \mathrm{MA}$ - mass activity, PM-progressive motility (\%), LA-liveability (\%), ABN-abnormality $(\%)$, Conc-concentration (\%), Vol-volume (\%) and Temp-temperature $\left({ }^{\circ} \mathrm{C}\right)$

The effect of replacing synthetic antibiotic with varying levels of Moringa oleifera leaf extract (MLE) in Beltsville thawing Solution (BTS) on semen parameters of exotic boars

As presented in Table 2, all parameters except abnormality were significantly $(\mathrm{p}<0.05)$ influenced. Mass activity was highest at OgMLE (4.00) (penicillin and streptomycin) and lowest at 1gMLE (3.31). The mass activity scores obtained for OgMLE and other levels were similar to those reported by Vyt (2007) ( $\geq 3$ is considered good). The progressive motility $(\% \mathrm{PM})$ of the cells with $0.25 \mathrm{gMLE}$ $(60.93 \%)$ was the highest while 1gMLE $(53.85 \%)$ was lowest. MLE inclusions at 0 , 0.50 and $0.75 \mathrm{~g}$ had 57.24, 59.94 and $58.77 \%$ progressive motility respectively. The PM was slightly lower than the range (62.9 - 68.3\%) reported by Vyt (2007). The variation between this study and other studies could have resulted from antibiotic difference, location, nutrition and innate traits. PH of semen decreased significantly $(p<0.05)$ with increasing levels of MLE, OgMLE had the highest (6.98) while 1gMLE had the lowest (6.90). Semen $p H$ which is an important indicator of seminal material quality were lower than ranges reported by Strzezek (1995) and Vyt (2007) and a possible explanation for this could be the extender dropping the $\mathrm{pH}$ of the raw boar semen (Tarek et al., 2014). The differences observed could have also arisen from antibiotics, MLE inclusion and lipid peroxidation. Liveability stood within normal limits (Shipley, 1999), 0.25g MLE $(86.40 \%)$ differed $(p<0.05)$ from others. The synergistic effects of antibiotics and other phytochemicals present in MLE could have played an important role in the liveability (Althouse and Lu, 2005). Percentage abnormality also remained within normal limits (<10\%) (Shipley, 1999). 
Table 2: The effect of replacing synthetic antibiotics with varying levels of Moringa oleifera leaf extract in Beltsville thawing solution on semen parameters of exotic boars

\begin{tabular}{llllll}
\hline MLE $(\mathrm{g})$ & Mass activity & $\begin{array}{l}\text { Progressive } \\
\text { motility }(\%)\end{array}$ & $\mathrm{pH}$ & $\begin{array}{l}\text { Liveability } \\
(\%)\end{array}$ & $\begin{array}{l}\text { Abnormality } \\
(\%)\end{array}$ \\
\hline 0 & $4.00^{\mathrm{a}}$ & $57.24^{\mathrm{c}}$ & $6.98^{\mathrm{a}}$ & $89.64^{\mathrm{a}}$ & 4.23 \\
0.25 & $3.64^{\mathrm{b}}$ & $60.93^{\mathrm{a}}$ & $6.92^{\mathrm{bc}}$ & $86.40^{\mathrm{b}}$ & 4.60 \\
0.50 & $3.63^{\mathrm{b}}$ & $59.94^{\mathrm{ab}}$ & $6.92^{\mathrm{bc}}$ & $88.20^{\mathrm{a}}$ & 4.53 \\
0.75 & $3.92^{\mathrm{b}}$ & $58.77^{\mathrm{bc}}$ & $6.94^{\mathrm{b}}$ & $89.48^{\mathrm{a}}$ & 3.94 \\
1 & $3.31^{\mathrm{c}}$ & $53.85^{\mathrm{d}}$ & $6.90^{\mathrm{c}}$ & $88.21^{\mathrm{a}}$ & 4.11 \\
$\pm \mathrm{SEM}$ & 0.043 & 0.703 & 0.013 & 0.478 & 0.242 \\
\hline
\end{tabular}

Means with different superscript $\mathrm{a}, \mathrm{b}, \mathrm{c}$ and $\mathrm{d}( \pm$ SEM) in the same column are significantly different $(\mathrm{p}<0.05)$

The effect of storage time on semen parameters of exotic boar extended with Beltsville thawing solution with varying inclusion of Moringa oleifera leaf (MLE) extract as replacement for synthetic antibiotics

Table 3 shows the effect of storage time on semen parameters of exotic boar extended with Beltsville thawing solution with varying inclusion of Moringa oleifera leaf (MLE) extract as replacement for synthetic antibiotics. All parameters were significantly $(p<0.05)$ influenced by storage period except abnormality. Mass activity, progressive motility and liveability followed similar trend, values decreased as the storage length increased. Semen examined at 0 hours had the highest value (4.98) while those at 72 hours recorded the least (2.42). At 0 hours, 84.26 and $99.01 \%$ was recorded while at 72 hours, 23.19 and $70.20 \%$ was obtained for progressive motility and liveability respectively. $\mathrm{PH}$ differed with 0 (7.02) and 24 hours (7.01) storage time statistically the same while 48 and 72 hours had 6.95 and 6.75 respectively. Semen parameters evaluated at 0 and 24 hours remained within the normal limit recommended by Shipley (1999) and Althouse and Lu (2005). However, the semen had lost it viability by 72 hours. The discrepancies observed could be as a result of differences in antibiotic, the MLE and the nature of the extender been used (Goldberg etal., 2013).

Table 3: The effect of storage time on semen parameters of exotic boar extended with Beltsville thawing solution with varying inclusion of Moringa oleifera leaf (MLE) extract as replacement for synthetic antibiotics

\begin{tabular}{llllll}
\hline Time (hour) & Mass activity & $\begin{array}{l}\text { Progressive } \\
\text { motility }(\%)\end{array}$ & $\mathrm{pH}$ & $\begin{array}{l}\text { Liveability } \\
(\%)\end{array}$ & $\begin{array}{l}\text { Abnormality } \\
(\%)\end{array}$ \\
\hline 0 & $4.98^{\mathrm{a}}$ & $84.26^{\mathrm{a}}$ & $7.02^{\mathrm{a}}$ & $99.01^{\mathrm{a}}$ & 3.96 \\
24 & $4.26^{\mathrm{b}}$ & $75.87^{\mathrm{b}}$ & $7.01^{\mathrm{a}}$ & $95.84^{\mathrm{b}}$ & 4.60 \\
48 & $2.98^{\mathrm{c}}$ & $49.26^{\mathrm{c}}$ & $6.95^{\mathrm{b}}$ & $88.50^{\mathrm{c}}$ & 4.26 \\
72 & $2.42^{\mathrm{d}}$ & $23.19^{\mathrm{d}}$ & $6.75^{\mathrm{c}}$ & $70.20^{\mathrm{d}}$ & 4.31 \\
\pm SEM & 0.038 & 0.629 & 0.011 & 0.427 & 0.216 \\
\hline
\end{tabular}

Means with different superscript a, b, c and d ( \pm SEM) in the same column are significantly different $(\mathrm{p}<0.05)$

The interactive effect between the different time of examination and the varying inclusion levels of MLE in boar semen extended with BTS

According to Table 4 values significantly differed $(\mathrm{P}<0.05)$ for mass activity $(\mathrm{MA})$, progressive motility $(\% \mathrm{PM}), \mathrm{pH}$ and liveability (\%LA) while abnormality $(\% \mathrm{ABN})$ was not significantly influenced.

Mass activity at $0 \mathrm{~g}, 0.50 \mathrm{~g}, 0.75 \mathrm{~g}$ and $1.00 \mathrm{~g}$ 
MLE had a score of five (5) while $0.25 \mathrm{~g}$ MLE had a score of 4.91 at 0 hours. At 24 hours, values obtained for $0 \mathrm{~g}(4.58), 0.50 \mathrm{~g}$ (4.41) and $0.75 \mathrm{~g}(4.33)$ MLE were the same while $0.25 \mathrm{~g}(3.87)$ and $1.00 \mathrm{~g}$ (4.08) were lower. At 48 hours of storage there was drop in MA, with the highest recorded at $0 \mathrm{~g}$ MLE (3.45) and the lowest at 1.00g MLE (2.33). At 72 hours, MA declined further with $0 \mathrm{~g}$ MLE having 2.95 while $1.00 \mathrm{~g}$ MLE had 1.83 although values recorded in 0.50 and $0.75 \mathrm{~g}$ MLE were similar. Progressive motility also differed $(\mathrm{p}<0.05)$, At 0 hours, $0.25 \mathrm{~g}$ MLE (88.54\%) was highest while $0.50 \mathrm{~g}(82.14 \%), 0.75 \mathrm{~g}(82.42 \%)$ and $1.00 \mathrm{~g}$ $(82.22 \%)$ were lowest. At 24 hours, PM declined with 0 (76.22), 0.25 (77.19) and $0.75 \mathrm{~g}$ MLE (77.65) having same values while $1.00 \mathrm{~g}$ (69.15) MLE was lowest. At 48 hours the decline continued with PM ranging from 43.73 to $55.06 \%$ for 1.00 and $0.25 \mathrm{~g}$ MLE respectively. At 72 hours the decline continued, $0.50 \mathrm{~g}(32.48 \%)$ MLE was highest while $0 \mathrm{~g}(14.01 \%)$ was lowest. The $\mathrm{pH}$ also differed $(\mathrm{p}<0.05)$, highest $\mathrm{pH}$ was obtained at $0 \mathrm{~g}$ MLE (7.04) at 24 hours while the lowest was obtained at $1 \mathrm{~g}$ MLE (6.63) at 72 hours. Percentage liveability was highest at $0 \mathrm{~g}$ MLE $(99.62 \%)$ at 0 hours and lowest at $0.25 \mathrm{~g}(66.29 \%)$ and $1 \mathrm{~g}$ MLE $(67.06 \%)$ at 72 hours. MA, PM, ABN, LA and $\mathrm{PH}$ recorded at 0 and 24 hours for 0 , $0.25,0.50,0.75$ and $1.00 \mathrm{~g}$ MLE stood within normal limits required for insemination and are in line with reports of Vyt (2007) who also reported similar results. The ability to maintain semen viability exhibited by MLE is in accordance with report by Fahey (2005) who reported the inhibitory effect of MLE.

Table 4: The interactive effect between the different time of examination and the varying inclusion levels of MLE in boar semen extended with BTS

\begin{tabular}{|c|c|c|c|c|c|c|}
\hline $\begin{array}{l}\text { Treatment } \\
\text { (MLE) }\end{array}$ & $\begin{array}{l}\text { Time } \\
\text { (Hour) }\end{array}$ & Mass activity & $\begin{array}{l}\text { Progressive } \\
\text { motility (\%) }\end{array}$ & $\mathbf{P}^{\mathrm{H}}$ & $\begin{array}{l}\text { Liveability } \\
(\%)\end{array}$ & $\begin{array}{l}\text { Abnormality } \\
(\%)\end{array}$ \\
\hline \multirow[t]{4}{*}{0} & 0 & $5.00^{\mathrm{a}}$ & $85.96^{\mathrm{ab}}$ & $7.04^{\mathrm{ab}}$ & $99.62^{\mathrm{a}}$ & 3.77 \\
\hline & 24 & $4.58^{b}$ & $76.22^{d}$ & $7.04^{\mathrm{a}}$ & $98.05^{\mathrm{abc}}$ & 4.92 \\
\hline & 48 & $3.45^{\mathrm{d}}$ & $52.37^{\mathrm{fg}}$ & $7.00^{\mathrm{abc}}$ & $86.64^{\mathrm{f}}$ & 3.75 \\
\hline & 72 & $2.95^{\mathrm{efg}}$ & $14.01^{\mathrm{m}}$ & $6.85^{\mathrm{e}}$ & $74.23^{g}$ & 4.46 \\
\hline \multirow[t]{4}{*}{0.25} & 0 & $4.91^{\mathrm{a}}$ & $88.54^{\mathrm{a}}$ & $7.00^{\mathrm{abc}}$ & $98.71^{\mathrm{ab}}$ & 4.94 \\
\hline & 24 & $3.87^{\mathrm{c}}$ & $77.19^{d}$ & $6.97^{\mathrm{abcd}}$ & $94.36^{\mathrm{d}}$ & 4.99 \\
\hline & 48 & $3.04^{\mathrm{ef}}$ & $55.05^{f}$ & $6.90^{\mathrm{de}}$ & $86.22^{\mathrm{f}}$ & 4.52 \\
\hline & 72 & $2.70^{\mathrm{g}}$ & $22.91^{\mathrm{kl}}$ & $6.77^{\mathrm{f}}$ & $66.29^{\mathrm{i}}$ & 3.93 \\
\hline \multirow[t]{4}{*}{0.50} & 0 & $5.00^{\mathrm{a}}$ & $82.14^{b c}$ & $7.03^{\mathrm{ab}}$ & $99.13^{\mathrm{a}}$ & 4.06 \\
\hline & 24 & $4.41^{\mathrm{b}}$ & $78.73^{\mathrm{cd}}$ & $7.02^{\mathrm{ab}}$ & $94.57^{d}$ & 4.87 \\
\hline & 48 & $2.87^{\mathrm{fg}}$ & $46.38^{\mathrm{hi}}$ & $6.92^{\mathrm{de}}$ & $87.27^{\mathrm{f}}$ & 4.48 \\
\hline & 72 & $2.20^{\mathrm{h}}$ & $32.48^{j}$ & $6.70^{\mathrm{fg}}$ & $71.81^{\mathrm{h}}$ & 4.71 \\
\hline \multirow[t]{4}{*}{0.75} & 0 & $5.00^{\mathrm{a}}$ & $82.42^{\mathrm{bc}}$ & $7.03^{\mathrm{ab}}$ & $98.86^{\mathrm{ab}}$ & 3.59 \\
\hline & 24 & $4.33^{b}$ & $77.65^{d}$ & $7.00^{\mathrm{ab}}$ & $96.28^{\mathrm{bcd}}$ & 4.20 \\
\hline & 48 & $3.16^{\mathrm{e}}$ & $48.76^{\mathrm{gh}}$ & $6.96^{\mathrm{bcd}}$ & $91.18^{\mathrm{e}}$ & 3.89 \\
\hline & 72 & $2.37^{\mathrm{h}}$ & $26.22^{\mathrm{k}}$ & $6.75^{f}$ & $71.59^{\mathrm{h}}$ & 4.05 \\
\hline \multirow[t]{4}{*}{1} & 0 & $5.00^{\mathrm{a}}$ & $82.22^{\mathrm{bc}}$ & $7.02^{\mathrm{ab}}$ & $98.69^{\mathrm{ab}}$ & 3.44 \\
\hline & 24 & $4.08^{c}$ & $69.15^{\mathrm{e}}$ & $7.00^{\mathrm{abc}}$ & $95.91^{\mathrm{cd}}$ & 3.99 \\
\hline & 48 & $2.33^{\mathrm{h}}$ & $43.73^{\mathrm{i}}$ & $6.93^{\mathrm{cde}}$ & $91.15^{\mathrm{e}}$ & 4.61 \\
\hline & 72 & $1.83^{\mathrm{i}}$ & $20.29^{1}$ & $6.63^{g}$ & $67.06^{\mathrm{i}}$ & 4.38 \\
\hline \pm SEM & & 0.0845 & 1.1018 & 0.0208 & 0.7188 & 0.4208 \\
\hline
\end{tabular}

Means with different superscript a- $\mathrm{m}( \pm$ SEM $)$ in the same column are significantly different $(\mathrm{p}<0.05)$

*MLE- Moringa leaf extract, MA- mass activity, PM-progressive motility (\%), LA-liveability (\%), $\mathrm{ABN}$-abnormality $(\%)$, Conc-concentration $(\%)$, Vol-volume $(\%)$ and Temp-temperature $\left({ }^{0} \mathrm{C}\right)$ 


\section{Conclusion}

This study concluded that the inclusion of 0.75-1.00g methanolinated Moringa Leaf Extract in the Beltsville Thawing Solution as replacement for synthetic antibiotic compared well at $0-24$ hours.

\section{References}

Afolabi, A. O., Hameed, A. A. and Alagbonsi, I. A. 2013. Effects of Methanolic Extract of Moringa oleifera Leaves on Semen and Biochemical Parameters in Cryptorchid Rats. African Journal of Traditional Complement Alternative Medicine, 10(5):230235

Althouse, G. C. and Lu, K. G. 2005. Bacteriospermia in extended $\mathrm{p}$ o $\mathrm{r}$ c i n e $\mathrm{s}$ e $\mathrm{m} \mathrm{e} \mathrm{n}$. Theriogenology63(2): 573-584.

Casewell, M., Friis, C., Marco, E., McMullin, P. and Philips, I. 2003. The European ban on growth promoting antibiotics and emerging consequences for human and animal health. Journal of Antimicrobial Therapy, 52: 159161.

Ewuola, E. O. and Egbunike, G. N. 2010. Effects of dietary fumonisin $\mathrm{B}_{1}$ on the onset of puberty, semen quality, fertility rates and testicular morphology in male rabbits.The Journal of the society of Reproduction and fertility, 139: 439-445.

Fahey, J. W. 2005. Moringa oleifera: a Review of the medical evidence for its nutritional, therapeutic, and prophylactic properties. Part 1," Trees for Life Journal, 1: 5-7.

Goldberg, A. M., Argenti, L. E., Accin, J. E., Linck, L., Santi, M., Bernardi, M. L., Cardoso, M. R., Wentz, I. and Bortolozzo, F. P. 2013. Risk factors for bacterial contamination during boar semen collection. Research in Veterinary Science, 95(2):362-367.

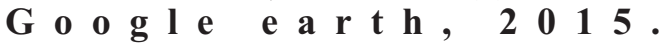
http://www.earth.google.com. Google earth version 7.1.5.1557. Date assessed. Nov 30, 2015. (C) digitalglobe, 2015.

Hafez, E. S. E. 1993. Reproduction in Farm Animals, 6th Edition, Ed. Lea \& Febiger, Philadelphia.

Hirai, M. and Boersma, A. 2001. Objectively measured sperm motility and sperm head morphometry in boars (Sus scrofa): relation to fertility and seminal plasma growth factors. Journal of Andrology 22(1): 104-110.

Johnson, L. A., Weitze K. F., Fiser, P., and Maxwell, W. M. 2000. Storage of b o a $\mathrm{r}$ s e men. Animal Reproduction Science: 62: 143-172.

King, G. J. and Macpherson, J. W. 1973. A Comparison of Two Methods for Boar Semen Collection. Journal of Animal Science 36: 563 - 565.

Kommisrud, E., Paulenz, H., Sehested, E., and Grevle, I. 2002. Influence o f b o a $\mathrm{r}$ a $\mathrm{d}$ s e m e $n$ parameters on motility and acrosome integrity in liquid boar semen stored for five days. Acta Veterinaria Scandinavica, 43: 49-55.

Levis, D. G. 2000. Liquid boar semen production: current extender technology and where do we go from here. In: Proceedings IV International Conference on Boar Semen Preservation, 1999, Beltsville, MD. Lawrence, KS: Allen Press. Pp: 121-128.

NRC, 2005. Effect of Environment on Nutrient Requirements of Domestic Animals. National Academy Press, Washington, DC: 105-108. 
Rao, R. R., George, M. and Pandalai, K. M. 1946. Pterygospermin: the Antibacterial Principle of Moringa pterygosperma, Gaertn. Nature, 158:745-746.

Shipley, C. 1999. Breeding soundness examination of the boar. Swine Health and Production, 7(3): 117120.

Siddhuraju, P. and Becker, K. 2003. Antioxidant properties of various solvent extracts of total phenolic constituents from three different agroclimatic origins of drumstick tree (Moringa oleifera Lam.) leaves ournal of Agricultural and Food Chemistry, 51(8): 2144-2155.

Sone, M. 1990. Investigations on the control of bacteria in boar semen. Japanese Journal of Animal Reproduction 36: 23-29.
Strzežek, J., Korda, W., Glogowski, J., Wysocki , P., and Borkowski, K., 1995. Influence of Semencollection Frequency on Sperm Quality in Boars, with Special Reference to Biochemical Markers, 1995, Reproduction in Domestic Animals, 30(2): 85-94.

Tarek, K., Constantinos, R., Foteini, S., Aristotelis.L., Kostas, K., and Toni, D., 2014. Highlights on Artificial Insemination (AI) Technology in the Pigs. Macedonian Veterinary Review; 37 (1): 5-34.

Turba, M. E., Fantinati, P., Bernadini, C., Gentilini, F., Bacci, M. L. and Forni, M. 2007. Relationships between innovative and traditional parameters to investigate semen quality in pigs, Animal Reproduction Science, 99:72-81.

Received: $19^{\text {th }}$ September, 2020 Accepted: $20^{\text {th }}$ December, 2021 